STUDIA POLONIJNE

T. 40. LUBLIN 2019

DOI: http://dx.doi.org/10.18290/sp.2019.10

MARIA ANNA FURTAK

\title{
KSIEGG JUBILEUSZOWE POLSKICH PARAFII W STANACH ZJEDNOCZONYCH JAKO ŹRÓDLO DO BADAŃ NAUKOWYCH
}

W ramach funkcjonowania polskich parafii rzymskokatolickich w Stanach Zjednoczonych, oprócz spełniania roli religijnej i duszpasterskiej, znajdowało się także celebrowanie ważnych dla danej społeczności dat, ich upamiętnianie. Popularnym tego przejawem były tzw. księgi jubileuszowe - parish jubilee books i pamiętniki-commemoration books. Przyjmowały one formę niewielkich broszurek, książeczek czy też mających monumentalne rozmiary kilkusetstronicowych ksiąg, stając się jednym $\mathrm{z}$ wielu przejawów wszechstronnej działalności Polonii amerykańskiej ${ }^{1}$. Mimo iż nie sporządzano ich dla celów naukowych, zawierają wiele danych na temat życia tamtejszych religijnych wspólnot, dlatego też celem niniejszego artykułu będzie przedstawienie charakteru powstających na przestrzeni dziesiątków lat istnienia amerykańskiej Polonii jubilee books oraz określenie ich roli jako nośników informacji przydatnych dla dzisiejszej nauki. Podstawę źródłową stanowić będzie około 30 jubilee books pochodzących z różnych okresów (od 1898 do 2015 r.) i będących wzorcowymi publikacjami tego typu, aby uchwycić i wyodrębnić główne ich cechy oraz etapy ewoluowania Polonii zapisane na ich kartach.

Pierwsze jubilee books polskich parafii zaczęto publikować na początku XX wieku². Powstające od III ćwierci XIX stulecia religijne wspólnoty właśnie w tym momencie mogły obchodzić tzw. srebrne jubileusze, czyli okrągłe, 25. rocznice

\footnotetext{
Mgr Maria ANNA FurTAK - doktorantka, Instytut Historii na Wydziale Nauk Humanistycznych Katolickiego Uniwersytetu Lubelskiego Jana Pawła II; e-mail: furtakma@gmail.com

${ }^{1} \mathrm{O}$ roli ksiąg jubileuszowych wspomina w krótkim artykule s. M.L. PAKowsKa, Ksiegi parafialne jako cenny materiat, „Biuletyn Polski” PAT 5 lutego 1944, nr 26/272, s. 1-2, oraz ks. dr Roman NIR w: Źródła do historii Polonii, Orchard Lake 1982, s. 92-93.

2 „Przyjętym jest u nas zwyczajem, że z okazji jubileuszów parafie i towarzystwa wydają pamiętniki, w których opisują działalność wybitniejszych jednostek" (M. HaIman, Historia St. Stanislaus Bishop\&Martyr Parish, Buffalo 1873-1923, [w:] Księga pamiątkowa Złotego Jubileuszu Osady Polskiej i Parafji św. Stanistawa B. i M. w Buffalo, New York, 1873-1923, oprac. F.E. Fronczak, New York 1923, s. 16).
} 
istnienia ${ }^{3}$, celebrowane uroczyście ze względu na fakt, iż parafie mogły poszczycić się już pewną historią, dokonaniami, które należało wyeksponować ${ }^{4}$. Księgi jubileuszowe były zatem wyrazem wdzięczności za otrzymane łaski, za wzmocnienie wiary i przywiązania do „Prawdziwego Kościoła Chrystusowego”. Ponadto ukształtowała się już świadomość polonijna, przez co możliwe stało się zdefiniowanie tego osiągnięcia, jakim była organizacja własnej, etnicznej parafii, co w większości przypadków wymagało wielkiego i długotrwałego wysiłku całej wspólnoty. Księgi wydawano i wydaje się nadal z okazji okrągłych jubileuszy ${ }^{6}$, tj. 25-lecia (silver jubilee), 50-lecia (golden jubilee), 75-lecia (diamond jubilee), 100-lecia (centenary), 150-lecia ${ }^{7}$, choć istnieją również nieliczne przypadki ksiąg pamiątkowych innych, niebędących jubileuszami rocznic ${ }^{8}$. Uroczyste świętowanie różnego rodzaju jubileuszy było zwyczajem, który narodził się wśród polskich emigrantów osiadłych na terenie Stanów Zjednoczonych, nie występował bowiem wcześniej na ziemiach polskich ${ }^{9}$.

Autorami tych pamiętników były zazwyczaj osoby wchodzące w skład komitetów jubileuszowych, których nazwiska wymieniane są na kartach jubilee books ${ }^{10}$. W niewielu przypadkach za spisanie historii parafii odpowiadali proboszczowie (np. Alfons M. Figlewski OMC z kościoła pw. St Stanislaus Kostka w Baltimore, ks. J. Sonnefeld CSSP z kościoła Niepokalanego Serca NPM w Pittsburghu) lub historycy (np. M. Haiman).

${ }^{3}$ Dzieje parafii Świętej Trójcy 1873-1898, Chicago.

4 „Są w życiu ludzi i narodów chwile ważne, których rocznica z większą radością i z uroczystą powagą bywa obchodzona. Jedną z takich rocznic jest dwudziestopięciolecie urodzin. Cieszy się dwudziestopięcioletni młodzieniec, że z dziecięcia, które o własnych siłach nawet kroku nie mogło zrobić, wyrósł na dzielnego, silnego młodziana, który i sam siebie utrzymuje, a także drugim jest pomocą i pożytkiem. I słusznie się cieszy!" (Silver Jubilee St. Stanislaus Bishop\&Martyr, Detroit 1898-1923, [b.n.s.]).

5 Pamiętnik Srebrnego Jubileuszu Parafii Wniebowzięcia N.M.P., Detroit, 1912-1937, [b.n.s.].

${ }^{6}$ „Wyraz jubileusz pochodzi z hebrajskiego wyrazu ,jubal’, głos trąb, którym ogłaszano początek każdego lata miłościwego, przypadającego u Izraelitów co pięćdziesiąt lat. W takim roku jubileuszowym otrzymywał każdy niewolnik, a z nim i jego rodzina, wolność, role, zastawione za długi, wracały do ich właściciela, stąd ogólna radość panowała. Wyraz jubileusz oznacza więc wielką radość z powodu jakiego szczęśliwego wypadku, a takim szczęśliwym wypadkiem było przed 25-laty założenie nowej parafii św. Stanisława B\&M" (Silver Jubilee St. Stanislaus Bishop\&Martyr, Detroit 1898-1923, [b.n.s.]).

7 St Stanislaus Parish, Milwaukee at 150 Years 1866-2016; Immaculate Conception of Blessed Virgin Mary, Panna Maria, Texas: Celebrating 150 Years 1854-2004.

${ }^{8}$ Np. St Hyacinth Parish $95^{\text {th }}$ Anniversary, Detroit 1907-2002.

9 J. Radzilowski, A Social History of Polish-American Catholicism, "U.S. Catholic Historian" 27(2009), nr 3, s. 32.

${ }^{10}$ Np. St Ladislaus Parish $75^{\text {th }}$ Anniversary 1920-1995, Hamtramck. 
Źródła do sporządzenia jubileuszowych ksiąg stanowiły kroniki parafialne ${ }^{11}$, sprawozdania, a także relacje naocznych świadków, którzy bezpośrednio uczestniczyli w organizowaniu parafii ${ }^{12}$. Powodem tworzenia jubilee books była chęć upamiętnienia, wyraz zewnętrznego kultu, radość z widocznego rozwoju wspólnoty, podanie do wiadomości informacji o działaniach parafian (często w obliczu trudności $)^{13} \mathrm{i}$ ich podsumowanie, „bo każdy będzie mógł uprzytomnić sobie nasze działanie, rozwój, wzrost od początku, aż do chwili obecnej"14, przy zachowaniu obiektywizmu i kronikarskiej rzetelności ${ }^{15}$. M. Haiman, historyk dziejów Polonii amerykańskiej, we wstępie do historii parafii św. Stanisława Biskupa i Męczennika w Buffalo zarzucił jednak zbytnią idealizację występującą w jubilee books ${ }^{16}$.

Kolejne jubileusze były ważnymi wydarzeniami dla parafii. Zazwyczaj towarzyszyły im kilku- lub kilkunastodniowe uroczystości (w tym bankiety, koncerty $^{17}$ ), na które zapraszano duchownych i wiernych z sąsiednich parafii czy hierarchów kościelnych ${ }^{18}$. Opisy tych wydarzeń często pojawiały się również w lokalnych gazetach ${ }^{19}$.

Programy tych często doniosłych i wystawnych uroczystości znaleźć można na stronicach licznych ksiąg ${ }^{20}$. Rangę tego typu wydarzeń i przepych im towarzyszący usprawiedliwiano potrzebą kultu zewnętrznego, znajdującym uzasadnienie w naturze człowieka, i obok kultu wewnętrznego, którym jest zwrócenie myśli i serca do

${ }^{11}$ Ztoty Jubileusz Parafii Niepokalanego Serca Najświętszej Maryi Panny, Pittsburgh 18971947.

12 Pamiętnik Parafii Św. Trójcy w Chicago 1893-1918, s. 3; Golden Jubilee of Immaculate Conception Parish. Souvenir labum 1882-1932, Chicago 1932, [b.n.s.].

${ }^{13}$ Holy Trinity Church in Chicago Centennial Year 1873-1973, [b.n.s.].

${ }^{14}$ Pamiatka Srebrnego Jubileuszu Parafii Najświętszej Marii Panny Anielskiej 1899-1924 $w$ Chicago, s. 5.

15 „Układając księgi dziejów parafii naszej staraliśmy się przede wszystkiem o przedstawienie faktów historycznych w świetle właściwem, a przynajmniej w takiem, w jakiem one nam się przedstawiały" (Dzieje parafii Św. Trójcy 1873-1898 w Chicago, [b.n.s.]).

${ }^{16}$ „Z konieczności w takich przypadkach pisze się pochwały hojniej, niźli potrzeba” (Księga pamiątkowa Złotego Jubileuszu Osady Polskiej, s. 16).

17 Np. Holy Trinity Church in Chicago Centennial Year 1873-1973, [b.n.s.]; St Michael Church the $75^{\text {th }}$ Anniversary Year. Commemoration Book 1892-1967, Chicago, s. 30-37.

${ }_{18}$ Golden Jubilee of Immaculate Conception, Chicago, 1882-1932, s. 57-59; Diamond Jubilee of St Mary of Angels 1899-1974, Chicago, s. 66-76.

19 Np. Jubileusz Parafii p.w. ŚŚ. Piotra i Pawła w Chicago, „Dziennik Chicagoski” 2 sierpnia 1920, s. 6; Srebrny Jubileusz Parafii św. Wojciecha w Chicago, „Dziennik Chicagoski” 22 kwietnia 1899, s. 2; Wielkie Święto Parafii. Z przebiegu uroczystości Diamentowego Jubileuszu Par. Św. Wawrzyńca, Phila., Pa., „Gwiazda Polarna” 21 listopada 1957.

${ }^{20}$ Pamiętnik Złotego Jubileuszu Parafii Św. Stanisława Biskupa i Męczennika w New York, 1874 1924, s. 76-78; St Michael Archangel 25 ${ }^{\text {th }}$ Anniversary Book, Chicago 1917, [b.n.s.]. 
Boga, wyrażającym całość religijności wspólnoty ${ }^{21}$. „Gdzie nie ma kościoła, nie ma władzy moralnej, stałej, pewnej, tam nie ma i uczucia powszechnego narodowego. Bez religii objawionej i bez władzy, naród jest jak bez serca i głowy"22. Uroczyste obchody kolejnego roku istnienia wspólnoty były zatem nie tylko formą wyrazu pobożności, ale również przywiązania do tradycji i polskości. Powstające na początku XX wieku księgi jubileuszowe miały, oprócz funkcji upamiętniającej, nieść pewną wartość duchową, ukazywać radość z ogromnego, wręcz niewyobrażalnego wysiłku parafian, jakim było organizowanie własnej wspólnoty parafii od podstaw.

Zawartość większości ksiąg i pamiętników jubileuszowych jest podobna, celem było pełne przedstawienie obrazu danej parafii z jej historią, osiągnięciami, działalnością, religijnością, budowaniem tradycji. Wyróżnić można następujące elementy najczęściej występujące, takie jak: geneza i dalsze dzieje parafii, historia budowy kościoła (zazwyczaj pierwszego, prowizorycznego, potem stałego), lista i biogramy duchowieństwa posługującego w parafii ${ }^{23}$, członkiń zgromadzeń zakonnych ${ }^{24}$, biogramy nauczycieli szkół parafialnych ${ }^{25}$, listy powołań zakonnych z parafii ${ }^{26}$, informacje o szkołach, ochronkach i innych instytucjach przyparafialnych ${ }^{27}$, listy i opis towarzystw parafialnych, a także różnego rodzaju ogłoszenia reklamowe. W wielu przypadkach jubilee books natrafić można ponadto na historię danej miejscowości oraz tamtejszej społeczności polskiej w szerszym spektrum ${ }^{28}$ i krótkie biogramy zasłużonych dla parafii osób świeckich i ich rodzin ${ }^{29}$.

Wszystkie te elementy okraszone są nawiązaniem do wiary przodków. Przejawia się ono w dedykacjach, napomnieniach, radach na temat prawdziwie chrześcijańskiego życia, wezwaniach i odniesieniach do Boga i modlitwach ${ }^{30}$. Świadczy to

${ }^{21}$ Pamiątka Srebrnego Jubileuszu Parafii Matki Bożej Pocieszenia w Mount Carmel 1896-1921, s. 32 .

22 Tamże, s. 33.

${ }^{23}$ Silver Jubilee St. Stanislaus Bishop\&Martyr, Detroit 1898-1923, s. 4; s. 14-15; St John of God, Golden Jubilee 1907-1957, Chicago, s. 12-15; Diamond Jubilee of St Mary of Angels 1899-1974, Chicago, s. 29.

${ }^{24}$ St Mary of the Angels Church, Chicago. Golden Jubilee 1899-1949, [b.n.s.].

25 Golden Jubilee of Immaculate Conception, Chicago, 1882-1932, s. 85-87.

${ }^{26}$ St Michael Church the 75 ${ }^{\text {th }}$ Anniversary Year. Commemoration Book 1892-1967, Chicago, s. 27.

27 St John of God, Golden Jubilee 1907-1957, Chicago, s. 25-26.

${ }^{28}$ Dzieje parafii Świętej Trójcy 1873-1898, Chicago, s. 5-6; Księga pamiątkowa Złotego Jubileuszu Osady Polskiej, [b.n.s.]; Golden Jubilee of Immaculate Conception, Chicago, 1882-1932, s. 22-24.

${ }^{29}$ Golden Jubilee of Immaculate Conception, Chicago, 1882-1932, s. 88-130; Pamiętnik Srebrnego Jubileuszu Parafii M.B. Królowej Apostołów w Hamtramck, Michigan, 1917-1942, s. 27-43.

${ }^{30}$ Ztoty Jubileusz Parafii Św. Stanistawa Kostki w Baltimore, 1881-1931, s. 29-35; Pamiętnik Parafii św. Stanisława Biskupa i Męczennika w Chicopee, Mass, Złoty Jubileusz 1891-1941, s. 35-36. 
zarówno o przywiązaniu do religii i silnej wierze ich twórców, jak i o więzi z tradycjami przywiezionymi z Polski.

Księgi otwierają wizerunki ówczesnych hierarchów ${ }^{31}$ Kościoła: papieża, biskupów, wraz z życzeniami i gratulacjami z okazji jubileuszowego święta para$\mathrm{fii}^{32}$, jak również dedykacje, w których autorzy poświęcają jubilee books m.in. dawnym parafianom, dziękując im za trud budowania wspólnoty ${ }^{33}$, lub hierarchom kościelnym $^{34}$. Świadczy to o poczuciu przynależności parafii do Kościoła amerykańskiego, mimo ich etnicznego charakteru i często napiętych relacji z miejscową diecezją ${ }^{35}$.

Część odnosząca się do historii zawiera najważniejsze wydarzenia danej wspólnoty: dokładnie opisana jest geneza jej powstania, stopniowe odnajdywanie przez Polaków zamieszkujących dany obszar wspólnych celów, etapy pozyskiwania zgody biskupa, zakup działek pod przyszłe zabudowania parafialne. Impulsem do zorganizowania parafii przez polskich emigrantów były przede wszystkim potrzeby religijne, ale także związane z rodzącą się świadomością etniczną pragnienie posiadania polskiego kapłana, słuchania nauk i kazań w ojczystym języku, kultywowanie polskich tradycji religijnych ${ }^{36}$. Czynnik ten jest podkreślony w wielu księgach jubileuszowych, które obrazują również w tym miejscu charakterystyczne dla Polonii przełomu XIX i XX wieku dążenia do jednoczenia się, nawiązywania współpracy, m.in. w postaci bractw i towarzystw religijnych, które zainicjowały powstanie wielu parafii na terenie $\mathrm{USA}^{37}$. O tym, jak ważni dla kolejnych pokoleń byli założyciele parafii i pierwsi jej członkowie, świadczyć mogą listy ich wymieniające $^{38}$. Jest to widoczne zwłaszcza w księgach złotych i diamentowych jubi-

${ }^{31}$ Biskupi często byli osobiście zaangażowani w organizowanie polonijnych parafii, por. M.J. Madaj, The Polish Immigrant and the Catholic Church in America, „Polish American Studies” 6(1949), nr 1/2, s. 6-8; M. Haiman, Historia St. Stanislaus, s. 23.

${ }^{32}$ Np. od prezydenta L.B. Johnsona - St Stanislaus Kostka, Chicago, Centennial 1867-1967, s. 15; arcybiskupa Chicago Johna kard. Cody'ego - St Hyacinth Chicago, Diamond Jubilee 18941969, [b.n.s.].

33 St Ladislaus Parish $75^{\text {th }}$ Anniversary 1920-1995, Hamtramck, [b.n.s.]; St Josaphat $75^{\text {th }}$ Anniversary, Chicago, 1884-1959, Chicago 1959, s. 4; St Mary of the Angels Church. Golden Jubilee 1899-1949, [b.n.s.].

${ }^{34}$ Diamond Jubilee: Immaculate Conception of BVM, Chicago 1957, s. 5.

35 P. TARAs, Parafia polonijna jako instytucja duszpasterska i problemy wynikajace z jej struktury i funkcji, ,Studia Polonijne” 2(1977), s. 79-80.

${ }^{36}$ Golden Jubilee 1904-1954 St Adalbert's Parish, Philadelphia, Philadelphia 1954, s. 18.

${ }^{37}$ Ksiega pamiatkowa Złotego Jubileuszu Osady Polskiej, s. 33-34; M.J. MadAJ, The Polish Immigrant, s. 4.

38 St Michael Archangel 25 $5^{\text {th }}$ Anniversary Book, Chicago, 1917, [b.n.s.]; Golden Jubilee of Immaculate Conception, Chicago, 1882-1932, [b.n.s.]. 
leuszy, gdzie wydawać by się mogło, że tak odległe informacje ulegną zatarciu i zapomnieniu.

Autorzy historii polskich parafii na kartach jubilee books, dla ukazania pełni obrazu dziejów danej parafii, nie unikają pisania o różnego rodzaju problemach, jakie towarzyszyły powstawaniu nowej wspólnoty i życiu parafialnej społeczności. Są to konflikty spowodowane przez niechęć lub niezrozumienie parafian i duchownych, niechęć do łożenia na parafię, konflikty o szerszym zasięgu, głosy krytyki ${ }^{39}$, związanych z nieporozumieniami z amerykańską hierarchią kościelną ${ }^{40}$, sporami wśród Polonii ${ }^{41}$, kłopotami finansowymi, zdarzeniami losowymi, lokalnymi warunkami ${ }^{42}$. Wskazuje to na dążenie do obiektywizmu w przedstawianiu historii danej wspólnoty, jej pełnego, prawdziwego obrazu.

Parafie nie powstawały bez ponoszenia trudów, potrzeba było wielu wyrzeczeń ze strony wiernych. Liczne księgi jubileuszowe kładą więc nacisk na wysiłek, jaki ponieśli parafianie - głównie niskopłatni robotnicy fabryk, w budowaniu własnej wspólnoty ${ }^{43}$. W wielu z nich pojawiają się dokładne listy zebranych na potrzeby parafii datków, listy ofiarodawców, a także listy przedmiotów zakupionych przez parafian do świątyni ${ }^{44}$. Obok przykładów ofiarności, na kartach jubilee books zauważyć można informacje o niezadowoleniu ${ }^{45}$.

Kluczowym elementem w dziejach każdej polskiej parafii w Stanach Zjednoczonych była budowa kościoła, stanowiącego centrum parafii ${ }^{46}$ („Kościół dla nas Polaków jest twierdzą i ostoją zarówno Wiary, jak i polskości") ${ }^{47}$, początkowo prowizorycznego, często drewnianego, mieszczącego w swoim wnętrzu również szkołę lub mieszkania dla duszpasterzy, po świątynię właściwą, często monumentalną, swoim ogromem i przepychem kontrastującą ze skromnym stylem życia większości przedstawicieli Polonii, jednak będącą symbolem jej przywiązania do wartości religijnych, oraz wyrazem kultu. Szczegółowo przedstawione są momenty związa-

39 Silver Jubilee St. Stanislaus Bishop\&Martyr, Detroit 1898-1923, s. 6; Pamiatka Srebrnego Jubileuszu Parafii Najświętszej Marii Panny Anielskiej 1899-1924 w Chicago, s. 21; Golden Jubilee of Immaculate Conception, Chicago, 1882-1932, [b.n.s.].

${ }^{40}$ St Hedwig Parish Silver Jubilee, Detroit, 1903-1928, [b.n.s.].

${ }^{41}$ Pamiętnik Parafii Św. Trójcy w Chicago 1893-1918, s. 6-15.

${ }^{42}$ Pamiętnik Srebrnego Jubileuszu Parafii Wniebowzięcia N.M.P., Detroit, 1912-1937, s. 2.

${ }^{43}$ Pamiatka Srebrnego Jubileuszu Parafii Matki Bożej Pocieszenia w Mount Carmel 1896-1921, s. 34; J. Radzilowski, A Social History of Polish-American Catholicism, s. 35-37; J. Окоцоwicz, Wychodźstwo i osadnictwo polskie przed I wojna światowa, Warszawa 1920, s. 429-430.

${ }^{44}$ Pamiętnik Parafii św. Stanisława [...] 1891-1941, s. 27.

45 Pamiatka Srebrnego Jubileuszu Parafii Matki Bożej Pocieszenia w Mount Carmel 1896-1921, s. 34 .

${ }^{46}$ P. Fox, The Poles in America, New York 1922, s. 92.

${ }^{47}$ Pamiętnik Parafii św. Stanistawa [...] 1891-1941, s. 5. 
ne z pozyskiwaniem funduszy na ten cel, kupowanie niezbędnych do budowy materiałów, wymieniane są nazwiska architektów czy budowniczych, opisy architektoniczne nowo powstałej świątyni ${ }^{48}$, koszty budowy kościoła ${ }^{49}$, co podnosi wartość informacyjną jubilee books i świadczy o skrupulatności ich autorów w ukazywaniu minionych zdarzeń - mają je jak najwierniej przedstawić, jak również ukazać poniesione koszty i wysiłki parafian, często sięgające wysokich kwot.

Dalsze losy parafii również zostały utrwalone na kartach jubileuszowych publikacji. Poświęcenie kamienia węgielnego czy potem właściwego budynku kościoła stanowią ważne momenty w opisywanych historiach, podobnie jak informacje na temat wizytacji biskupów ${ }^{50}$ czy innych znanych osób, np. generała Józefa Hallera ${ }^{51}$, biskupa Franciszka Symona ${ }^{52}$, Ignacego Jana Paderewskiego ${ }^{53}$.

Księgi kolejnych jubileuszy opisują też obchody poprzednich uroczystości, np. silver jubilee, jubileuszy kapłaństwa duchownych ${ }^{54}$. Część ta staje się coraz bardziej rozbudowana $\mathrm{z}$ każdą kolejną jubilee book, jednakże w wielu przypadkach historia najwcześniejsza bywa dosłownie cytowana w nowszych księgach (np. Golden jubilee St Hyacinth Church 1894-1944 i St Hyacinth Parish 1894-1969 Diamond Chicago).

W tle wielu narracji można dostrzec zarys ogólnoamerykańskiej historii Polonii - starania o polskiego biskupa ${ }^{55}$, formowanie się Kościoła Polskokatolickiego, działalność organizacji takich, jak Związek Narodowy Polski czy Zjednoczenie Polskie Rzymskokatolickie, dzięki czemu możliwe jest wskazanie, iż dana parafia funkcjonuje i funkcjonowała jako część całej społeczności. Podobną rolę pełniły także wzmianki o wydarzeniach w USA i reakcjach Polonii na nie, takie jak np. udział w obu wojnach światowych, wielki kryzys lat 30. XX wieku ${ }^{56}$.

Ponadto w jubilee books opisywane są zasłużone dla danej parafii osoby, przede wszystkim duszpasterze. Poprzez zamieszczanie ich biogramów oraz często fotografii odzwierciedlano rolę księży i sposób postrzegania ich przez Polonię jako

${ }^{48}$ Silver Jubilee St. Stanislaus Bishop\&Martyr, Detroit 1898-1923, s. 20.

${ }^{49}$ Pamiętnik Parafii Św. Trójcy w Chicago 1893-1918, s. 44, 57.

${ }^{50}$ Tamże, s. 20.

${ }^{51}$ Pamiątka Srebrnego Jubileuszu Parafii Najświętszej Marii Panny Anielskiej 1899-1924 $w$ Chicago, s. 109-110.

${ }^{52}$ St Hedwig Parish Silver Jubilee, Detroit, 1903-1928, [b.n.s.].

53 St John of God, Golden Jubilee 1907-1957, Chicago, s. 27.

${ }_{54}$ Tamże, s. 28; St Stanislaus Kostka, Chicago, Centennial 1867-1967, s. 36, 42, 44; Diamond Jubilee of St Mary of Angels 1899-1974, Chicago, s. 22-23.

${ }_{55}$ St Michael Archangel 25 ${ }^{\text {th }}$ Anniversary Book, Chicago, [b.n.s.].

${ }^{56}$ Pamiętnik Ztotego Jubileuszu Parafii Św. Stanisława Biskupa i Męczennika w New York, 1874 1924, s. 105. 
przywódców nie tylko duchowych, ale także jako pionierów, społecznych budowniczych tych małych wspólnot, w których toczyło się życie religijne i rozwijała kultura przywieziona z Ojczyzny ${ }^{57}$.

Księgi jubileuszowe wyrażają ponadto rangę znaczenia, jakie miały parafie dla Polonii ${ }^{58}$. Były one porównywane w swojej roli do rodzin, najmniejszych jednostek społeczeństwa: parafianie mieli być członkami rodziny Kościoła, kościół parafialny - ich domem, parafia - „ojczyzną dusz naszych"59. Jej głównej funkcji upatrywano w oświecaniu, pocieszaniu i wskazywaniu drogi do nieba ${ }^{60}$, rozwijaniu duchowości i zapobieganiu wynarodowieniu i zgnuśnieniu ${ }^{61}$. „Parafia to prawdziwa społeczność żyjąca"62. To parafie były miejscami, gdzie Polacy-tułacze ${ }^{63}$, „w zapędach emigracyjnych w tułaczej drodze znaleźli Stany Zjednoczone", znajdowali swoje miejsce do życia, „ostoję, gdzie ideały religijne, moralne i narodowe płonąć miały dlań i dzieci ich niewygasłym żarem" ${ }^{4}$.

Oprócz tego, parafie miały przekazywać tradycje przywiezione z Ojczyzny, wyuczone przez przodków, ich język, kulturę, pamięć, być ich depozytami ${ }^{65}$.

Te założenia realizowano również dzięki szkołom parafialnym. Jak wynika $\mathrm{z}$ informacji zawartych w większości jubilee books ${ }^{66}$, zorganizowanie takiej szkoły było jedną z pierwszych czynności podejmowanych przez członków powstającej parafii. O roli szkół parafialnych wyrażano się w następujący sposób: „to twierdza polskości i fundament religijności.[...] jest ciężarem koniecznym dla naszego bytu narodowego i religijnego"67.

57 J. RadzILowski, A Social History, s. 30; Księga pamiatkowa Złotego Jubileuszu Osady Polskiej, s. 127; S. Osada, Jak się ksztaltowała polska dusza Wychodźstwa w Ameryce, Pittsburgh 1930, s. 11.

58 „Parafia to kolebka Polaków tutejszych, którzy dopiero od chwili zjednoczenia się pod godłem Krzyża I rozpoczęcia budowy własnego kościoła zaczęli rość w siłę i znaczenie i dziś [...] mogą patrzeć na stutysięczną przeszło kolonię polską, liczne świątynie i szkoły [...] na tysiące Polaków stojących pod sztandarem polskich organizacji” (Księga pamiątkowa Złotego Jubileuszu Osady Polskiej, [b.n.s.]).

${ }^{59}$ Golden Jubilee 1904-1954 St Adalbert's Parish, Philadelphia, s. 4.

${ }^{60}$ Tamże; Pamiętnik Złotego Jubileuszu Parafii Św. Stanisława Biskupa i Męczennika w New York, 1874-1924, s. 8.

${ }^{61}$ Pamiętnik Srebrnego Jubileuszu Parafii MB Pocieszenia, Mount Carmel, s. 33.

${ }^{62}$ Golden Jubilee 1904-1954 St. Adalbert's Parish, Philadelphia, s. 4.

${ }^{63}$ St Michael Archangel 25 ${ }^{\text {th }}$ Anniversary Book, Chicago, s. 5.

${ }^{64}$ Pamiętnik Ztotego Jubileuszu Parafii Św. Stanisława Biskupa i Męczennika w New York, 1874 1924, s. 8.

${ }^{65}$ Pamiętnik Srebrnego Jubileuszu Parafii MB Pocieszenia, Mount Carmel, s. 44.

${ }^{66} \mathrm{O}$ historii szkoły np. w: Historia szkoły, [w:] St Stanislaus Bishop\&Martyr Diamond Jubilee, New York 1874-1949, s. 77-88.

${ }^{67}$ Pamiatka Srebrnego Jubileuszu Parafii Najświętszej Marii Panny Anielskiej 1899-1924 w Chicago, s. 191. 
Mimo iż zdecydowaną większość polskiej emigracji do USA na przełomie XIX i XX wieku tworzyli ludzie pochodzenia chłopskiego, sami często niewykształceni, dostrzegali oni potrzebę uczenia swoich dzieci ${ }^{68}$. Ta nauka patriotyzmu dawała znać o sobie w kluczowych dla Polski momentach, przede wszystkim w czasie I wojny światowej, gdy żyjący na terenie Stanów Zjednoczonych Polacy wstępowali do nowo powstającej Armii Hallera lub też armii amerykańskiej (obie wojny światowe) ${ }^{69}$. Na kartach wielu jubilee books można natrafić na wzmianki o parafianach, którzy w ten sposób chcieli dopomóc Krajowi Przodków ${ }^{70}$. Oprócz tego, organizowano składki, zbiórki darów dla potrzebujących w Polsce. Uroczyście obchodzono też polskie święta narodowe czy rocznice upamiętniające wybitnych Polaków ${ }^{71}$.

W obserwowaniu, jaki rzeczywiście był obraz danej parafii zawarty w jubilee books, przydatne są informacje o bractwach i towarzystwach religijnych (różańcowych, modlitewnych, męskich, żeńskich), chórach, towarzystwach oszczędnościowych ${ }^{72}$, komitetach parafialnych. Elementy te dają możliwość ujrzenia, jak funkcjonowały społeczności parafialne, czym zajmowali się ich przedstawiciele, jaką klasę społeczną stanowili, jak ważne były dla nich przejawy religijności, jakie działania dla ulepszenia społeczności podejmowali. Ważne okazują się także różnego rodzaju statystyki, np. odnoszące się do liczby wiernych, udzielonych sakramentów ${ }^{73}$, liczby dzieci uczęszczających do parafialnej szkoły ${ }^{74}$, sumy zebranych datków i wiele innych. Daje to możliwość obserwacji rozrastania się parafii, zwiększania lub zmniejszania liczby parafian, stopnia ich zamożności czy zaangażowania w życie wspólnoty.

Reklamy, bardzo często występujące zwłaszcza w księgach kolejnych jubileuszy, stanowią pewnego rodzaju źródło historyczne. Będące ogłoszeniami lokalnych polonijnych przedsiębiorstw, pomagają zorientować się, czym parafianie danej wspólnoty się zajmowali lub też jakie rodzaje usług były dostępne w dzielnicach

68 S. OsADA, Jak się ksztaltowała polska dusza, s. 10.

${ }^{69}$ St Stanislaus [...] New York 1874-1949, s. 95-99.

${ }^{70}$ Pamiętnik Srebrnego Jubileuszu Parafii MB Pocieszenia, Mount Carmel, s. 38; Księga pamiatkowa Złotego Jubileuszu Osady Polskiej, s. 139-146 i 177-186.

${ }^{71}$ Holy Trinity Church in Chicago Centennial Year 1873-1973, [b.n.s.]; St Stanislaus [...] New York 1874-1949, s. 92, 101.

72 Np. Pamiętnik Złotego Jubileuszu Parafii Św. Stanisława Biskupa i Męczennika w New York, 1874-1924, s. 30, 52-56.

${ }^{73}$ Ksiegga pamiatkowa Złotego Jubileuszu Osady Polskiej, s. 109-110; Diamond Jubilee of St Mary of Angels 1899-1974, Chicago, s. 24; St Michael Church the $75^{\text {th }}$ Anniversary Year. Commemoration Book 1892-1967, Chicago, s. 23-25, 28-29; St Hyacinth Church. Golden Jubilee 1894-1944, Chicago, s. 56.

${ }^{74}$ Pamiętnik Srebrnego Jubileuszu Parafii M.B. Królowej Apostołów w Hamtramck, Michigan, 1917-1942, [b.n.s.]. 
przez nich zamieszkałych. Zamieszczanie reklam w jubilee books to przejaw wpływu kultury amerykańskiej i przykład przenikania się obu tradycji: polskiej i amerykańskiej, wynikiem czego jest amerykańska Polonia, ze swoim unikatowym, hybrydowym charakterem.

Świadomość funkcjonowania w rzeczywistości amerykańskiej uwidacznia wielu autorów jubilee books, zarówno starszych, jak i nowszych ${ }^{75}$, gdzie poruszane są informacje na temat wkładu Polaków w historię USA, wzmiankowane wydarzenia polityczne, wizyty polityków etc. Jest to wyrazem poczucia, iż Polonia stanowi swoiste połączenie: czynnik polski funkcjonujący na ziemi amerykańskiej, które są ze sobą nierozerwalnie związane i wzajemnie dopełniające się.

Nieodzownym elementem występującym w jubilee books są fotografie, ukazujące wszystkie główne aspekty życia parafii: budynek kościoła, wizerunki duszpasterzy, członków bractw parafialnych, obchody świąt. Stanowią one cenne źródło historyczne, również dla badaczy architektury i sztuki, ponieważ ukazują obiekty z biegiem lat często zmienione przez remonty lub już nieistniejące (np. Saint John of God w Chicago). Księgi nowsze zawierają, obok zdjęć współczesnych, także fotografie archiwalne ${ }^{76}$, co pozwala na poczynienie obserwacji dotyczących zmian np. wystroju wnętrza kościoła.

Jubilee books dotykają wszystkich aspektów życia parafii: tworzących ją ludzi, ich pobożności, ich dzieła, jakim było organizowanie wspólnoty i budowa kościoła, poczucia przynależności do amerykańskiego społeczeństwa i tamtejszej struktury kościelnej. Zawierają dzięki temu wiele różnego rodzaju informacji i szczegółów, które ukazują wieloaspektowy obraz społeczności, pozwalają zaobserwować rozwój polonijnej kultury, jej ewolucję i mogą stać się źródłem i punktem wyjścia do dalszych badań.

Dla historyka stanowią katalogi najważniejszych wydarzeń związanych z organizowaniem parafii. Można je uznać za zapis życia parafii w danym momencie jej istnienia, obraz taki, jaki jawił się w oczach ówczesnych parafian, tego, jak postrzegali oni przeszłość swojej wspólnoty, jaki mieli stosunek do polskiego dziedzictwa i tradycji. Ważna jest kwestia obiektywizmu, księgi jubileuszowe nie są bowiem opracowaniem naukowym, informacje w nich zawarte mogą okazać się nieprecyzyjne, zwłaszcza iż $\mathrm{w}$ wielu przypadkach bywały zaczerpnięte $\mathrm{z}$ niepewnych źródeł. Oprócz tego, pojawia się pytanie, czy kolejne księgi jubileuszowe są źródłem pierwotnym, czy też wtórnym, ponieważ wiele z nich bazuje na zapiskach ksiąg wcześniejszych.

\footnotetext{
${ }^{75}$ Np. St Barbara Church. Golden Jubilee, Chicago, 1910-1960, [b.n.s.]; Księga pamiatkowa Ztotego Jubileuszu Osady Polskiej, s. 19.

76 St Josaphat Parish Centennial, 1883-1983, Chicago, Chicago 1983.
} 
Dużą wartość informacyjną mają różnego rodzaju statystyki, dzięki czemu możliwa staje się obserwacja stopnia rozwoju parafii na przestrzeni lat, jej liczebności, poziomu religijności wiernych. Ze względu na fakt, iż dane te nie są pełne, mogą inspirować do podjęcia dalszych badań, w celu wskazania, co określone procesy powodowało, jakie zjawiska społeczne zachodziły w obrębie parafii, i przełożenia tego na ogólną historię polskich parafii w USA.

Ponadto w jubilee books zauważalny jest socjologiczny wpływ parafii na daną wspólnotę, związany np. z rozwojem organizacji, szkół, podejmowaniem różnych inicjatyw. Dzięki tym jubileuszowym publikacjom może być zaobserwowana także ewolucja społeczności polskiej w USA. Księgi jubileuszowe tworzone były na przestrzeni dziesięcioleci, obejmowały więc swoim zasięgiem kilka pokoleń. Pierwsze księgi srebrnych jubileuszy tworzone były zazwyczaj przez osoby bezpośrednio uczestniczące $\mathrm{w}$ organizowaniu parafii, tzn. świeżo przybyłych emigrantów, nieznających języka angielskiego ani amerykańskich realiów, odnajdujących się w nowej rzeczywistości dzięki wytworzonej wokół siebie polskiej społeczności. Kolejne księgi jubileuszowe (złote, diamentowe) sporządzane były przez następne pokolenia, potomków emigrantów, Amerykanów polskiego pochodzenia, można zaobserwować wśród nich częściowy ${ }^{77}$ (lub zupełny ${ }^{78}$ ) zanik znajomości języka polskiego ${ }^{79}$, jednak duże przywiązanie do przekazywanych przez parafię tradycji ${ }^{80}$. Śledzenie zmian w danej parafii dzięki księgom jubileuszowym prezentuje postępowanie zjawiska asymilacji z kulturą amerykańską $\mathrm{w}$ danej społeczności ${ }^{81}$, jak również procesów rozwojowych wśród całej Polonii w związku z wydarzeniami politycznymi i historycznymi, takimi jak na przykład odzyskanie przez Polskę niepodległości ${ }^{82}$.

Jubilee books, oprócz swoich kommemoratywnych funkcji, pełnią także rolę istotnego nośnika informacji na temat życia Polonii. Dostarczają danych związanych z religijnością, mikrohistorią społeczności polonijnej, makrohistorią USA, tamtejszą kulturą, sposobem życia, a które nie zostały ujęte w parafialnych zapi-

77 St Barbara Church. Golden Jubilee, Chicago, 1910-1960; St John of God. Golden Jubilee 1907-1957, Chicago.

${ }^{78}$ St Ladislaus Parish $75^{\text {th }}$ Anniversary 1920-1995, Hamtramck; St Josaphat $75^{\text {th }}$ Anniversary, Chicago, 1884-1959.

${ }^{79}$ W. Kорутко, Konsolidacja wychodźstwa polskiego w Stanach Zjednoczonych, Warszawa 1929, s. 76-87.

${ }^{80}$ K. Symonolewicz-Symmons, Ze studiów nad Poloniq amerykańska, Warszawa 1979, s. 45, 68.

81 J. RADZILOwski, A Social History, s. 40; amerykanizacja postępowała wskutek chęci wybicia się poza środowisko polonijne, stąd zmniejszenie użycia języka polskiego; zmiany następowały także w wyniku polityki amerykańskiej i kościelnej; D.S. BuczeK, Parafia polsko-amerykańska jako czynnik amerykanizujacy, „Studia Polonijne” 6(1983), s. 151.

82 K. Symonolewicz-Symmons, Ze studiów nad Polonią, s. 42-43. 
skach i metrykach, które zazwyczaj są głównym źródłem do badań naukowych. Pozwalają dostrzec unikatowy charakter amerykańskiej Polonii, ale także proces jej ewolucji i kształtowania się na przestrzeni dziesięcioleci, a w niektórych przypadkach nawet wieków. Jako punkt wyjścia do badań w ramach różnych dziedzin nauki, są cenne dla historyków, historyków sztuki, socjologów badających stopień religijności bądź społeczne uwarunkowania grup polonijnych, etnologów. Jubilee books mogą być równocześnie potraktowane jako źródła do poszerzania wiedzy dla szerokiego grona odbiorców, ze względu na fakt, iż mają nienaukowy charakter oraz w większości przypadków nie zostały przygotowane przez profesjonalnych badaczy. Są jednym z wielu przykładów dziedzictwa Polonii amerykańskiej, zaś ich powstanie świadczy o wyjątkowości tej etnicznej społeczności w USA.

\section{BIBLIOGRAFIA}

\section{Źródla}

Pamiętnik Srebrnego Jubileuszu Parafii Wniebowzięcia N.M.P., Detroit, 1912-1937.

Dzieje parafii Świętej Trójcy 1873-1898, Chicago.

Diamond Jubilee: Immaculate Conception of BVM, Chicago 1957.

Golden Jubilee of Immaculate Conception Parish. Souvenir album 1882-1932, Chicago 1932.

Księga pamiątkowa Złotego Jubileuszu Osady Polskiej i Parafji św. Stanisława B. i M. w Buffalo, New York, 1873-1923, oprac. F.E. Fronczak, New York 1923.

Pamiątka Srebrnego Jubileuszu Parafii Najświętszej Marii Panny Anielskiej 1899-1924 w Chicago.

Pamiątka Srebrnego Jubileuszu Parafii Matki Bożej Pocieszenia w Mount Carmel 1896-1921. Pamiętnik Parafii Św. Trójcy w Chicago z okazji 25-tej rocznicy otwarcia kościoła 1893-1918. Pamiętnik Złotego Jubileuszu Parafii Św. Stanisława Biskupa i Męczennika w New York, 1874-1924.

Silver Jubilee St Stanislaus Bishop\&Martyr, Detroit 1898-1923.

Golden Jubilee 1904-1954 St Adalbert's Parish, Philadelphia, 1954.

St Barbara Church. Golden Jubilee, Chicago, 1910-1960.

St Hedwig Parish Silver Jubilee, Detroit, 1903-1928.

St Hyacinth Parish $95^{\text {th }}$ Anniversary, Detroit 1907-2002.

St Hyacinth Chicago, Diamond Jubilee 1894-1969.

St Hyacinth Church. Golden Jubilee 1894-1944, Chicago.

St John of God, Golden Jubilee 1907-1957, Chicago.

St Josaphat $75^{\text {th }}$ Anniversary, Chicago, 1884-1959.

St Josaphat Parish Centennial, 1883-1983, Chicago, Chicago 1983.

St Ladislaus Parish $75^{\text {th }}$ Anniversary 1920-1995, Hamtramck.

Diamond Jubilee of St Mary of Angels, Chicago, 1899-1974.

St Mary of the Angels Church, Chicago. Golden Jubilee 1899-1949. 
St Michael Church the $75^{\text {th }}$ Anniversary Year. Commemoration Book 1892-1967, Chicago. St Stanislaus Kostka, Chicago, Centennial 1867-1967.

St Stanislaus Parish, Milwaukee at 150 Years 1866-2016.

Holy Trinity Church in Chicago Centennial Year 1873-1973.

Immaculate Conception of BVM, Panna Maria, Texas: Celebrating 150 Years 1854-2004.

Pamiętnik Srebrnego Jubileuszu Parafii M.B. Królowej Apostołów w Hamtramck, Michigan, 1917-1942.

St Michael Archangel 25 $5^{\text {th }}$ Anniversary Book, Chicago, 1917.

Pamiętnik Parafii św. Stanisława Biskupa i Męczennika Chicopee, Mass, Złoty Jubileusz 1891-1941.

Złoty Jubileusz Parafii św. Stanisława Kostki w Baltimore, 1881-1931.

St Stanislaus Bishop\&Martyr Diamond Jubilee, New York, 1874-1949.

\section{Opracowania}

BuczeK D.S., Parafia polsko-amerykańska jako czynnik amerykanizujący, „Studia Polonijne" 6(1983).

Fox P., The Poles in America, New York 1922.

KорYтко W., Konsolidacja wychodźstwa polskiego w Stanach Zjednoczonych, Warszawa 1929.

Madaj M.J., The Polish Immigrant and the Catholic Church in America, "Polish American Studies" 6(1949), nr 1-2.

NIR R., Źródła do historii Polonii, Orchard Lake 1982.

OKoŁowicz J., Wychodźstwo i osadnictwo polskie przed I wojną światową, Warszawa 1920.

OsADA S., Jak się kształtowała polska dusza wychodźstwa w Ameryce, Pittsburgh 1930.

PAKowska M.L., Księgi parafialne jako cenny materiał, https://polona.pl/item/biuletyn-polski-1944-nr-26-nr-272-5-lutego 1944,ODIyNzc3MzU/0/\#info:metadata [dostęp: 11.02.2019].

Radzilowski J., A Social History of Polish-American Catholicism, „U.S. Catholic Historian" 27(2009), nr 3.

SymonolewiCZ-Symmons K., Ze studiów nad Polonią amerykańską, Warszawa: KAW 1979.

TARAS P., Parafia polonijna jako instytucja duszpasterska i problemy wynikające z jej struktury i funkcji, ,Studia Polonijne” 2(1977).

\section{KSIĘGI JUBILEUSZOWE POLSKICH PARAFII W STANACH ZJEDNOCZONYCH JAKO ŹRÓDŁO DO BADAŃ NAUKOWYCH}

\section{Streszczenie}

Amerykańska Polonia posiada bogatą historię i może poszczycić się wieloma osiągnięciami na różnych polach kultury. Wśród jej wytworów są tzw. jubilee books polskich parafii, powstające już od końca XIX wieku w celu upamiętnienia ważnych dla społeczności polskich wydarzeń. 
Te jubileuszowe publikacje odznaczają się bogactwem informacji i poruszają wiele zagadnień związanych z życiem parafii, właściwych także całej amerykańskiej Polonii. Z tego powodu stanowią źródło, cenne dla historyków, historyków sztuki, socjologów i innych badaczy zajmujących się tą polską diasporą.

Dlatego też celem niniejszego artykułu jest przedstawienie fenomenu jubilee books polskich parafii w Stanach Zjednoczonych, tego czym są, z jakich powodów powstawały i jakie są ich cechy charakterystyczne, jak również określenie ich roli w dzisiejszej nauce.

Słowa kluczowe: Polonia amerykańska; parafia etniczna; księga jubileuszowa; kultura Polonii

\section{PARISH JUBILEE BOOKS AS A SOURCE FOR SCIENTIFIC RESEARCH}

\section{Sum mary}

American Polonia has rich history and can be proud of many achievments on various fields of culture. Among them are jubilee books of Polish ethnic parishes, which have been published since the end of $19^{\text {th }}$ century in order to commemorate important events of Polish neighborhoods. These jubilee publications characterize with bunch of information and disclose many parochial questions, relevant also to whole American Polonia. Hence they are important source of scientific research for historians, art historians, sociologist and other American Polonia researchers.

This article aims to show the Polish parishes jubilee books in United States phenomenon, what they are, why they were prepared and what are their main features as well as - their importance and role in modern science.

Key words: American Polonia; ethnic parish; jubilee book; Polonia culture 